\title{
Integration of maintenance and production strategies under subcontracting constraint: Classification and opportunity
}

\author{
N. Hafidi*, A. El Barkany and M. Mahmoudi \\ Faculty of Sciences and technologies, Mechanical Engineering Laboratory, \\ Sidi Mohamed Ben Abdellah University, \\ Route d'Imouzzer, BP. 2202, Fes, Morocco \\ *Email: hafidi.nouhayla@gmail.com \\ Phone: +212611826833;
}

\begin{abstract}
The main concern of the manufacturing industry is maintaining the tools of production so that they are in good working order. However, the maintenance and production functions are linked because the integrated management of these two functions is necessary for the efficient operation of the means of production. In fact, when the demand exceeds the maximum production capacity, the company takes on subcontracting to meet the needs of the customers. The objective of this research is to identify the current and future direction of research in this field according to the different classification criteria proposed. In this paper, firstly, the different approaches of maintenance integrated into production systems are presented. Secondly, the models that deal with joint maintenance management and subcontracting production as a solution that aligns with the company's strategic objectives are discussed as well as the resolution and management approaches that integrated problem optimisation. Finally, a comparative study of existing approaches was conducted and their purpose analysed. As perspective, we will propose and implement in our future research a model and powerful tool to establish a better policy of maintenance integrated to the production using subcontracting.
\end{abstract}

Keywords: Production; maintenance; coupling; subcontracting; optimisation.

\section{INTRODUCTION}

The current manufacturing industry is characterised by strong competition to satisfy the needs of a clientele that is often demanding in terms of quality, cost, turnaround time and safety. To remain competitive, companies must control operating costs and optimise production facilities. To keep a good image of the company, it is necessary to respect the delivery time and the conformity of the customer's requirements. At the same time, it is necessary to develop technical strategies that improve the equipment productivity and availability because integrated maintenance combines both production and maintenance management (Figure 1). In the literature, several research studies have been carried out to confront the hybrid management of maintenance and production. The objectives of reference work [1] are to establish an economic production plan, as well as an optimal maintenance strategy in a sequential manner, minimising the total cost of production/inventory and the cost of maintenance. Then, the authors of reference [2] studied the integration of scheduling decisions in the case of a single machine for production and maintenance operations to, simultaneously; minimise production costs 
and maintenance costs. In addition, [3, 4] treated maintenance and production management in a joint way. Based on a semi-Markovian decision process and the stochastic dynamic programming method, the authors in [5] presented a model of interaction between maintenance and production. From that perspective, they have determined optimal production, repair/replacement and preventive maintenance policies for a degraded manufacturing system.

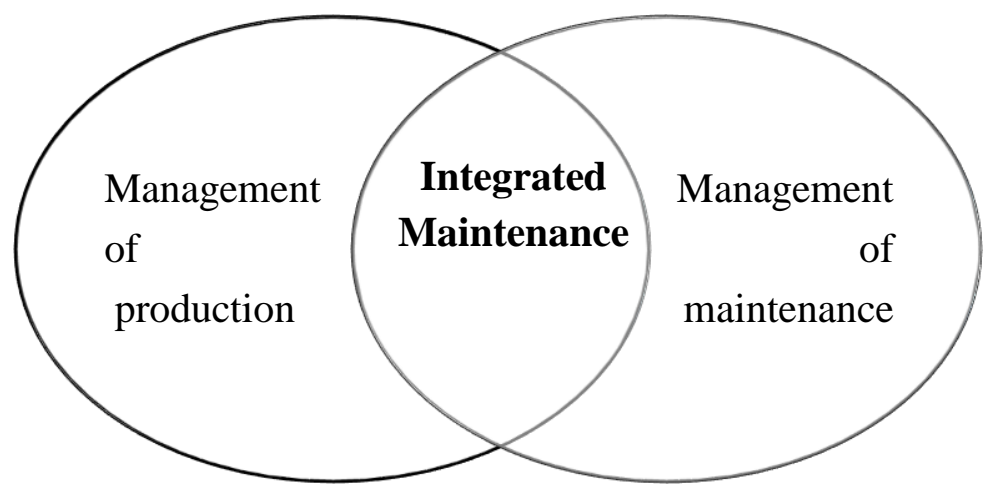

Figure1. The concept of maintenance integrated into production systems.

Sometimes, the integrated production and maintenance strategies are insufficient to minimise maintenance and operating costs in order to increase the availability of production systems and especially to meet a demand that is often diversified and superior to the maximum capacity of production. In such a situation where the company is forced to satisfy a demand that exceeds its production limits and to win new markets or just to preserve these potential customers, the company is obliged to resort to the outsourcing of the production system, which consists transferring all or a part of the quantity to be produced to an external partner [6,7]. The main industries considered are the automobile industry, the field of transport of petroleum products and the aeronautics industry. The stucture of this paper is as follows. After presenting the models that have dealt with the joint management of maintenance and production, we are dealing with the approaches to solve problems of joint optimisation of maintenance and production by introducing a comparative analysis of integrated maintenance models under subcontracting constraints. This leads to the identification of future research prospects.

\section{METHODS AND MATERIALS}

Effective bibliographic research requires an adequate research methodology. With the aim to cover the subject of integrated subcontracting maintenance, we opted for a literature review based on a database containing articles, conference papers and doctoral theses. As for the bibliography on integrated maintenance for production under subcontracting constraints, we have adopted several databases: Taylor \& Francis, Scopus, Thomson, Springer, Elsevier, Science Direct, IEEE Explore and Emerald Insight. We took note that the literature search was initiated on the descriptors "Integrated Maintenance" and "Subcontracting". In addition, several combinations of the above descriptors have also been developed to ensure correct and relevant results. After reviewing the literature, we have found 105 papers ( 5 doctoral reports and 103 scientific papers). Figure 2 shows the classification of references by year of publication. 
Table 1. Distribution of references according to the source.

\begin{tabular}{|c|c|c|}
\hline Source & Number & $\begin{array}{c}\% \text { of the } \\
\text { total }\end{array}$ \\
\hline International Journal of Production Research & 21 & 19 \\
\hline European Journal of Operational Research & 7 & 6 \\
\hline International Journal of Productivity and Quality & 1 & 1 \\
\hline Management & & \\
\hline Naval Research Logistics & 1 & 1 \\
\hline Computers and Industrial Engineering & 7 & 7 \\
\hline IEEE Transactions on Reliability & 1 & 1 \\
\hline Journal of Decision Systems & 1 & 1 \\
\hline International Journal of Production Economics & 11 & 11 \\
\hline Journal of Intelligent Manufacturing & 2 & 2 \\
\hline MOSIM'01 & 1 & 1 \\
\hline Information Sciences & 1 & 1 \\
\hline Interfaces & 1 & 1 \\
\hline INCOM'09 & 2 & 2 \\
\hline IIE transactions & 4 & 4 \\
\hline International Journal Mathematics In Operational Research & 1 & 1 \\
\hline MOSIM'10 & 2 & 2 \\
\hline Mathematical Problems In Engineering & 1 & 1 \\
\hline Computers and Operations Research & 4 & 4 \\
\hline OMEGA-International Journal of Management Science & 2 & 2 \\
\hline Journal of Quality In Maintenance Engineering & 4 & 4 \\
\hline International Conference on Industrial Engineering and & 2 & 2 \\
\hline $\begin{array}{l}\text { Production Management } \\
\text { IEEE Conference on Automation Science and Engineering }\end{array}$ & 3 & 3 \\
\hline IFAC Papers Online & 2 & 2 \\
\hline Journal of The Operational Research Society & 1 & 1 \\
\hline CIRP Annals- Manufacturing Technology & 2 & 2 \\
\hline Reliability Engineering and System Safety & 4 & 4 \\
\hline International Journal Advanced Manufacturing Technology & 2 & 2 \\
\hline International Journal Advanced Operations Management & 1 & 1 \\
\hline IFAC'11 & 3 & 3 \\
\hline International Journal of Management Science and & 1 & 1 \\
\hline Engineering Management & & \\
\hline International Journal and Systems Engineering & 1 & 1 \\
\hline Journal Européen des systèmes Automatisés (JESA) & 1 & 1 \\
\hline SysTol'10 & 1 & 1 \\
\hline Applied numerical mathematics & 1 & 1 \\
\hline Mathematical and Computer Modelling & 1 & 1 \\
\hline EcoDesin'99 & 1 & 1 \\
\hline Total & 103 & 100 \\
\hline
\end{tabular}

As shown in Table 1, a group of three journals represents $37.00 \%$ of the references included in this work: International Journal of Production Research (19 references), International Journal of Production Economics (11 references) and Computers and Industrial Engineering ( 7 references). They were followed by the 
European Journal of Operational Research (6 references) and Reliability Engineering and System Safety (4 references) which represent a $10.00 \%$ set of the examined items. The remaining 31 journals published comprised of $53.00 \%$ of the total considered references. Most of the problems of joint management of production and maintenance strategies have recently generated an increasingly fertile field for research as the number of publications has increased in recent years (Figure 2). Beyond that, from integrated maintenance to production, several research studies have considered the subcontracting constraint of production as a favourable solution that satisfies the requirements of the customer.

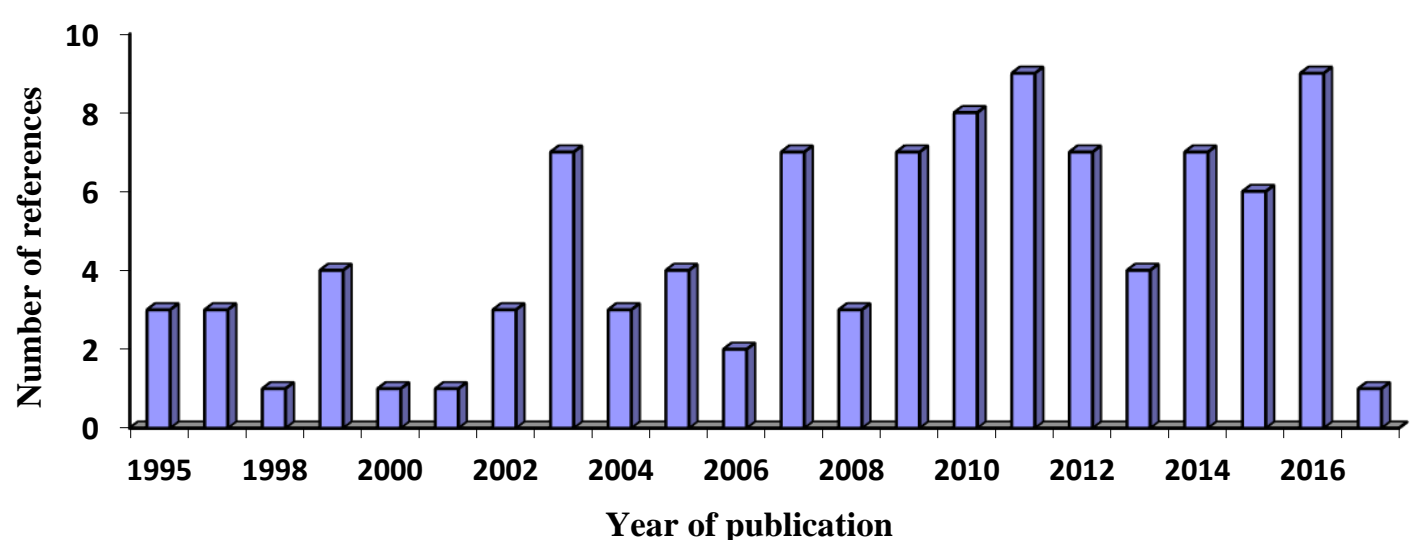

Figure 2. Sorting by year of publication.

\section{Separate Management of Maintenance and Production}

Separate management of maintenance and production is manifested at the point where maintenance management does not consider the impact of production constraints and vice versa. Therefore, maintenance is often seen as a source of additional disruption to production and a cost function only, since both functions are always in conflict at the planning level as well as at the level of resource sharing. In addition, separate management of maintenance and production can lead to failure to comply with the preventive maintenance plan, resulting in the failure of production system equipment and failure to meet customer requirements, essentially in terms of delay, since compliance with the deadline is a high priority on the part of clients. The main challenge facing manufacturing is to produce more products using fewer resources [8].

The overlap between maintenance interventions and production operations is manifested at the production planning level, which requires the maximum availability of equipment as well as the maintenance planning that awaits production shutdown to carry out preventive maintenance interventions. The literature has treated the problem separately by considering each axis individually (production and maintenance). Given the models, either maintenance plans or production planning, reference [9] dealt with production planning, which consisted of satisfying customer orders by integrating quality to remain competitive. Moreover, the models of maintenance planning carried out in the literature did not explicitly consider their impact on production planning. Similarly, most production planning models do not consider the impact of corrective maintenance actions and preventive maintenance actions on their planning. Some authors proposed preventive maintenance policies regarding the critical age of the machine by comparing maintenance strategies to evaluate the performance of faulty production systems [10-12]. Similarly, the control of production systems under preventive maintenance was dealt with $[13,14]$ by developing an approach based on the Markov modelling. 


\section{Joint Management of Maintenance and Production Under Subcontracting Constraints}

\section{Integrated Production Maintenance}

In the industry, lack of communication and coordination between the production and maintenance departments creates a conflictual situation between these two services. Noncompliance with periods of preventive maintenance, unexpected shutdowns in production systems, as well as random demands contribute to disruption and loss of productivity, as the availability of equipment at the appropriate time is a necessary condition for the smooth running of production and for meeting delivery deadlines. The maintenance exceeds the function of equipment repair; this function requires serious deliberation that affects the efficiency of production [15]. So many characteristics present challenges to production planning and control activity in any remanufacturing system [16]. However, the execution of maintenance actions requires the shutdown of production systems. This shows that the maintenance and production functions are much attached. Despite all this, there is dissociation in the management of these two functions, particularly in the planning of their activities. Integrated management of maintenance and production has become a necessary solution for the proper functioning of the means of production.

Integrated maintenance can be defined as the combination of maintenance management and production management to avoid conflicts between both services and achieve maximum profit for the company. Consequently, the concept is increasingly adopted in the industrial context. This approach consists of considering simultaneously the production parameters (for example: production rate, inventory levels, customer demand, etc.) and maintenance (for example: the rate of breakdowns, the periodicity of preventive actions, etc.) (Figure 3). Hence, it is possible to optimise the overall functioning of several types of production systems, considering production capacity, the demand to be satisfied, the reliability of the equipment, the maintenance of the production tools, the cost of maintenance and the cost of production.

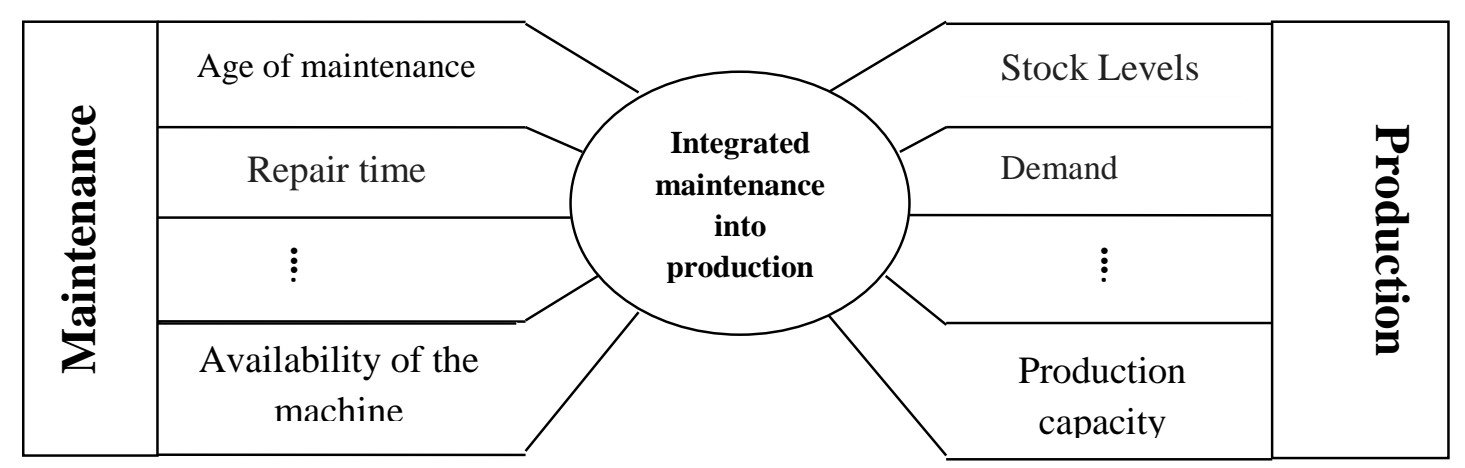

Figure 3. Integrated maintenance and production management

Joint management of production and maintenance is a problem that has been studied by several research works. In the literature, a relationship between maintenance and production was found. This relationship exists in many ways. Hence, the following distinctions were made. The paper classified integrated models of production and maintenance into four main categories. The first category represented models for joint optimisation of production and maintenance rates. This category has been dealt with by the references [17-25]. These models dealt with the problem of optimal flow control where the decision variables were production and maintenance rates. The goal was to 
minimise the cost of overhead and maintenance. In this sense, reference [26] amounted to simultaneously optimising the flows of production and preventive maintenance. The approach developed allowed considering the interaction between the maintenance strategy and the control policy. Other authors [27] proposed an extended linear programming model to calculate the optimal production plan with a minimum total cost. The problem of the dual objective of production planning and maintenance was treated as a mixed linear program. Some authors [28] presented the optimisation of preventive maintenance by a simulation model that combined maintenance and production. The intention was to simultaneously ensure a low frequency of failure by efficient periodic preventive maintenance and to minimise the unavailability of the production system, which implied a minimum impact on production. In the same context, reference [29] developed a combination of production and maintenance plan for a manufacturing system that satisfied a random demand. Joint optimisation was carried out to establish an optimal strategy for production and maintenance. The aim of [30] was to establish an economic production plan that satisfied a random demand, and an optimal preventive maintenance plan using the production plan was already established.

The second category developed models for joint planning of production and maintenance. However, the performance of maintenance and production management required their cooperation. The work of reference [31] dealt with the problem of maintenance planning. They offered some answers to the problem of the joint and integrated planning of maintenance and production tasks. Other authors [32] presented an integrated model of preventive maintenance production and planning for multi-state systems. On the production side, the model generated, for each product and production planning period, the quantity of inventory and the delivery time. On the maintenance side of each component, they proposed the time of each preventive maintenance action that can be carried out during the planning period of production. This is notably the case of reference [33], which addressed the problem of production planning, interacting with the environmental issue from a perspective of degradation by proposing and studying three production control policies and those of the revision policy concerning maintenance activities. The work by [34] focused on an integrated modelling method that simultaneously determined production planning and maintenance planning in the machining system, considering the replacement of the machine's failure tool, as well as the constant demand and possible shortage. Based on a linear mixed number programming model, the authors of reference [35] jointly planned the production and maintenance activities. The model considered the reliability (expected number of failures) of production costs, maintenance, shortages and demand. Preventive maintenance was performed on predetermined dates while corrective maintenance was performed to restore the system to an operating state without altering the failure rate function. In the same way, the aim was also to combine production and maintenance planning, this time in the context of a multi-product batch production system with faulty equipment [36]. Other authors [37] proposed joint production and maintenance models considering the uncertainty of yield, which helped avoid shortage of inventory and loss of customers. They formulated an integrated planning problem as a Markov decision process. In addition, they demonstrated that optimal production and maintenance policies had a control limit structure. The work by [38] dealt with integrated modelling of the scheduling of preventive maintenance and production activities. The reference [39] presented a joint model of production and maintenance planning for a production system subject to random failures. This model both reduced the shortage of demand and gave more flexibility to preventive maintenance actions. 
Table 2. Synthesis of integrated maintenance approaches to production

\begin{tabular}{|c|c|}
\hline Approaches & Authors \\
\hline $\begin{array}{l}\text { Optimisation of } \\
\text { production and } \\
\text { preventive } \\
\text { maintenance } \\
\text { policy }\end{array}$ & $\begin{array}{l}\text { Van der Duyn and Vanneste [13], Meller and Kim [14], Salameh } \\
\text { et al. [40], Ouali et al.[26], El-Kassar and Salameh [41], Rezg et } \\
\text { al.[42], Chelbi and Aï't Kadi [43], Kenné and al [44], Srinivasan } \\
\text { and Lee [45], Yalaoui and Chaabi [27], Roux et al.[28], Hajej } \\
\text { and Dellagi [29], Bergeron et al. [19], Gharbi and Kenne [18], } \\
\text { Hajej et al. [30], Weinstein and Chung [46], Yao et al. [47], } \\
\text { Iravani and Duenyas [48], Gharbi et al. [49], Liao et al. [50], } \\
\text { Berthaut et al. [51]. }\end{array}$ \\
\hline $\begin{array}{l}\text { Integrated } \\
\text { production and } \\
\text { maintenance } \\
\text { planning }\end{array}$ & $\begin{array}{l}\text { Bennour et al. [38], Brandolesse et al. [52], Cassady and } \\
\text { Kutanoglu [53], Pandey et al. [54], Hadidi and Al-Turki [55], F. } \\
\text { Hnaien et al.[56], Sortrakul et al. [57]. }\end{array}$ \\
\hline One 1 & $\begin{array}{l}\text { Restrepo et al. [58], Wang et al. [59], Berthaut et al. [60], } \\
\text { Cassady and Kuntanoglu [61], Cui et al. [62], Sortrakul and } \\
\text { Cassady [63], Mehdi et al.[64], Yulan et al. [65], Lu et al. [66]. }\end{array}$ \\
\hline Parallel machines & Berrichi et al.[67], Nourelfath and Châtelet [68]. \\
\hline $\begin{array}{l}\text { Integration of } \\
\text { production plans, } \\
\text { maintenance and } \\
\quad \text { quality }\end{array}$ & $\begin{array}{l}\text { Nourelfath et al. [69], Gouiaa-Mtibaa et al. [70], Ben-Daya et al. } \\
\text { [71], Ben-Daya et al. [72], Bouslah et al. [73], Colledani et al. } \\
\text { [74], Pandey and Kulkarni [75]. }\end{array}$ \\
\hline Multi-machine & Bajestani et al.[4], Gharbi and Kenné [22]. \\
\hline $\begin{array}{l}\text { Economic } \\
\text { quantity of } \\
\text { production } \\
\text { (EPQ) }\end{array}$ & $\begin{array}{l}\text { Abdulnour et al. [76], Groenevelt et al. [77], Makis and Fung } \\
\text { [78], Chung et al. [79], Ben-Daya et al. [72], Wang and Sheu } \\
\text { [80], Budai et al. [81]. }\end{array}$ \\
\hline
\end{tabular}

The third category concerned models with the objective of jointly determining the optimum size of a buffer stock and the optimal age of preventive maintenance. The authors of [44] proposed an analytical model to study the effect of the adopted preventive maintenance policy and the age of the equipment on the buffer stock levels. In addition, reference [82] also developed a mathematical model to find the optimal torque (buffer stock and preventive maintenance age) that minimised the average total cost per unit of time. In the same way, the authors of [42] presented a common optimisation between the age of preventive maintenance and the control stock in a production line consisting of $n$ machines. In developing an analytical model, the objective was to determine both the size of the buffer stock and the preventive maintenance period for an unreliable production unit that was subject to regular preventive maintenance of a random duration [83].

The last category dealt with the integration of three axes: production, maintenance and quality. In addition, the model integrating production, maintenance and process quality has been the subject of research [84]. The safety stock construction conditions based on the economic order quantity, denoted MEQ (Economic Manufacturing Quantity) were studied by [85]. Recently, the authors of [69] proposed a joint selection model for the optimal values of the production plan and maintenance policy, while taking into account the quality costs for an imperfect process. In the same vein, reference [73] addressed the joint optimisation of production, preventive maintenance and quality control using acceptance sampling plans, proposing a holistic 
approach to joint optimisation of production lot size, safety stock, acceptance sampling plan and revision schedule, considering a quality constraint for the degradation of production systems. In addition, the authors of [86] revised the methods and tools to support the strong interaction between production logistics, quality and maintenance functions. They also showed that performance improvement was achieved in relation to existing solutions, which dealt only with the aspects of quality. Table 2 focuses on the various approaches to integrated production maintenance that were developed between 1995 and 2016. Some authors positioned themselves at the level of optimisation of production and the policy of preventive maintenance, or the integrated planning of production and maintenance, by treating as an example the case of a single machine or parallel machines.

\section{Industrial Subcontracting}

The concept of outsourcing (or externalisation) has helped organisations reduce operating costs. Subcontracting is defined as the supply of goods or services according to the contractor's design and specifications [87]. Companies often outsource to organisations that possess complementary skills. In fact, the increasing use of subcontracting is a major structural change in the organisation of enterprises. French Law $n^{\circ} 75-1334$ of $31^{\text {st }}$ December 1975 on subcontracting defines subcontracting as the operation by which an entrepreneur (contractor) entrusts a subcontractor under his responsibility to another person called under -processing the performance of all or part of the contract of undertaking or part of the public contract concluded with the contracting authority. The subcontractor subcontracts the contractor while at work by supporting a part of the industrial risks generated by his work. Similarly, it is subordinated to the directives of the client who will be precise and elaborate, the minimum being the specifications [88]. Outsourcing has expanded in the industrial world in virtually all areas [89]. Outsourcing allows companies to react flexibly to market demands, to acquire the skills and professionalism that they do not have, to tighten their investment and hence their internal resources around their core business [90]. Other authors [91] have justified the use of subcontracting by insufficient internal technology to efficiently produce a product or the impossibility of producing the quantities requested within the specified time. In addition, outsourcing is a solution that allows companies to benefit from the complementary skills of external organisations. They also modelled the interaction between the employees of the "host" company and the outsourcing company. Moreover, subcontracting is considered by many industrialists as a necessity, the extent of which has been widely emphasised [31, 92]. It therefore represents not only an increasing share of activities, but has also become almost indispensable. The volume of outsourced hours has steadily increased and may represent a strong proposal for the number of hours worked [93].

\section{Different Types of Subcontracting}

Subcontracting can be described in three ways, depending on the point of view adopted: the means required for operations, the location of operations or the degree of subcontracting. Each of these three axes determines two categories of subcontracting:

- Subcontracting of capacity and subcontracting of specialty if one focuses on the means. The subcontracting of capacity constitutes a reinforcement of the activity; the user company itself is able to carry out a part of this activity [94]. On the other hand, specialty subcontracting refers to the taking over by a subcontractor of highly specialised activities in which the ordering firm does not provide at most [95]. 
- Internal subcontracting and external subcontracting if reference is made to the location. For internal subcontracting, it consists of a so-called "user" company, entrusting work to an outside company [93] on its own site and during its own activity. Outsourcing is particularly relevant to the automotive industry and telephone information [96].

- Subcontracting in cascade and subcontracting to a single rank according to the degree of subcontracting, when a user undertaking entrusts one or more operations to an outside undertaking under a contract of enterprise, the level 1 subcontracting undertaking entrusts in its turn all or part of the operations which have been entrusted to it to a third company. The latter then becomes a subcontractor company at level 2 . This type of subcontracting frequently allows meeting demands for flexibility and increases responsiveness of companies. An increase can be seen in the rate of temporary employees and fixed-term contracts among subcontractors of rank 2 and above $[93,95]$.

\section{Motivations of Subcontracting}

Outsourcing is not always justified by production costs. It is part of the logic of cooperation and coordination based, for example, on technological motivations, to satisfy the customers' needs in terms of time and quantity [97-99]. Sometimes, companies turn to external sources and collaborate with external partners to develop shared technological capabilities [100, 101]. The motivations that can lead a company to outsource part of its activities and trust a provider to achieve them can be summarised as follows:

Financial motivation: the financial aspect is one of the first reasons given in the literature, in line with the desire to reduce costs internally. Specialised firms have been able to rationalise their costs and offer services that enable the client to achieve productivity savings, even if internal resources exist [102, 103].

i) Strategic motivation: the user company selects the investments that appear to be the most creative in value [91]. In this case, it may decide to abandon activities that have the least added value in relation to its core business [104].

ii) Skill-based motivation: there are companies that are specialised in the outsourced activity and have competent staff, tools and materials needed to carry out the interventions $[92,104]$. This is a specialty outsourcing.

iii) Social motivation: reference [105] explained that subcontracting can be linked to a difficult social context and that it can be a means of circumventing the binding statutes of large order-giving companies.

\section{The Limits of Industrial Subcontracting}

The limits of outsourcing will be achieved when they impact the production tool. These limits may cause difficulty in retaining internal know-hows on sensitive equipment, even if complex operations are occasionally entrusted to specialists. In addition, there is a strong dependency to the subcontractor and lack of motivation for the subcontractor to improve the quality of the product [106].

\section{The problematic of joint management of maintenance and production under constraint of subcontracting}

The main objective of the manufacturing company is to increase productivity, with the aim to satisfy the customer's needs. To acquire new markets, the company applies outsourcing, which involves entrusting a part of its production to a service provider. To guarantee a win-win situation, the company adopts a new strategy to manage production and maintenance in a joint way. The issue of joint management of maintenance and 
production using subcontracting is addressed at several levels (Figure 4). First, the main concern of the ordering company is the choice of the most optimal subcontractor. This choice of subcontractor is based on several conditions, namely the cost of the minimum production, as well as the maximum availability of the subcontractor's equipment. Secondly, if the two companies are not generally located in the same geographical location, we are talking about offshoring. Therefore, the management of the maintenance of the two companies, the company ordering, and subcontracting remain ambiguous. Hence, the management of the maintenance and production of the subcontractor are not managed by the ordering company. The inefficiency and unavailability of the subcontractor's equipment will lead to costs of non-conformity of the manufactured products. For this reason, it is necessary to make a planning of the production actions for the ordering company at the level of determination of the quantity to be manufactured for the two companies, to respect the customer requirements in terms of time and quality.

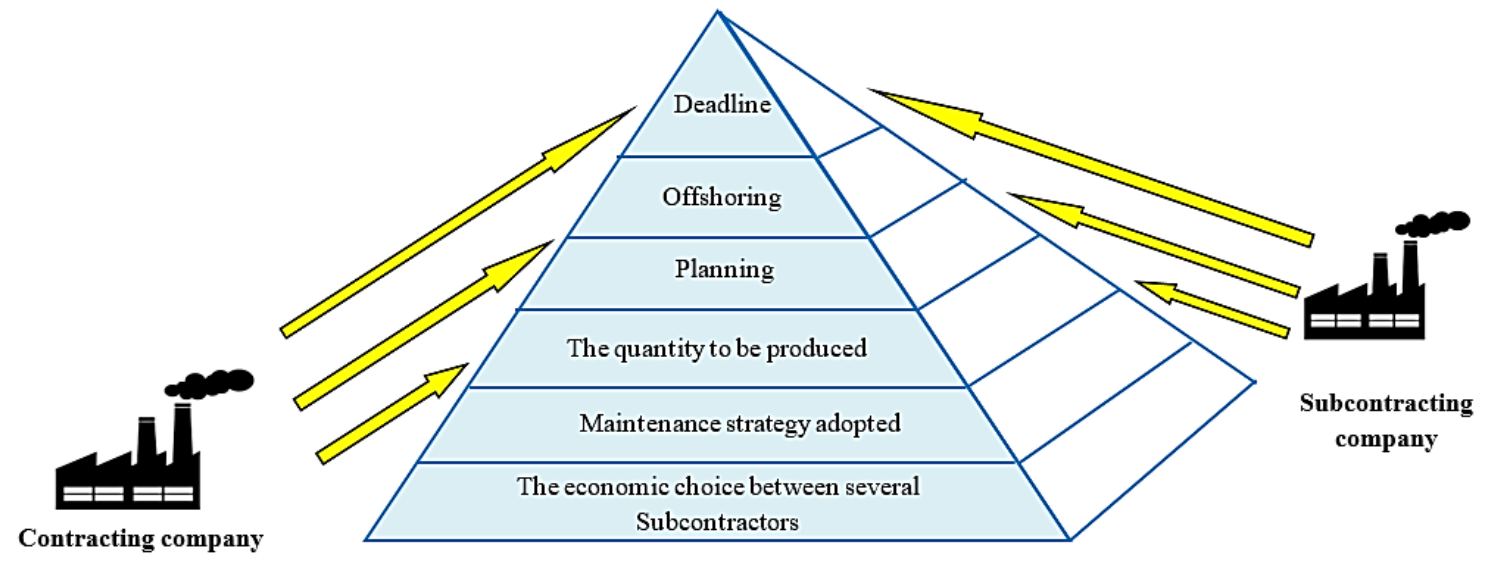

Figure 4. The problems of joint management of maintenance and production under the constraint of subcontracting.

\section{Integration approaches for maintenance and production using subcontracting}

The traditional approach that dissociates maintenance and production is not satisfactory in terms of time, cost and quality. The integration of joint management of maintenance and production has become necessary. The goal is to find an economical production plan, as well as an optimal maintenance strategy. When the demand exceeds the maximum production capacity, in such a situation where the company is obliged to satisfy a demand that exceeds its production limits to keep these customers, the latter uses subcontracting. Considering the preceding, the following questions arise. First, what is the basis of maintenance and production management for the contracting company and the subcontracting company? How can we balance production capacity constraints, customer demand and availability of equipment to achieve the most optimal result? How can the contracting company make an economic choice between several subcontractors? Here, the focus is not on theoretical applications, but on the joint management approaches for joint management of maintenance and production using subcontracting of existing systems.

Real and new strategies that consider the management of integrated maintenance under subcontracting constraints have been studied by [107] by providing a methodology for determining the level of the security stock and the storage capacity for multiple products of several manufacturing facilities with outsourcing options [107]. In this sense, reference [108] proposed a joint policy of joint production and subcontracting of 
unreliable production systems, based on an approach that includes experimental design, variance analysis, response surface methodology and simulation modelling. [108] achieved a reduction in the total cost incurred up to $20 \%$, compared to the results obtained by [107] when considering the customer satisfaction constraint. Other authors [109] have treated conditional maintenance for a production system that considered reliability aspects and environmental requirements to find the optimal inspection dates by considering the average cost of the cycle unit of time. To meet market demand, the manufacturer outsourced part of the demand to another entrepreneurial company. In the same context, a combinatorial approach to maintenance and production management in the case of outsourcing was developed by [110]. The objective of the work was to determine simultaneously for each period the optimal internal production as well as the rate of outsourcing. They used a genetic algorithm to optimise the total cost, including internal production, maintenance and shortage. In addition, reference [111] introduced environmental parameters in the analysis of the reliability of the equipment during its life cycle. These parameters considered human health, safety and the impact on the external environment.

Recently, a case study which proved the influence of the subcontractor's constraints on the optimal maintenance strategy adopted was presented in [112]. In their work, the authors of [113] developed and optimised a new maintenance policy while considering the constraints of subcontractors. They considered a production system represented by a machine producing a single type of product to satisfy a constant demand. The machine used the subcontracting represented by a second machine to complete the whole of the demand exceeding the maximum rate of the machine. Two preventive maintenance policies for the contractor machine were studied: the first did not consider the condition of the subcontracting machine, whereas the second did not. They showed that, under the given conditions, an improved maintenance policy could be achieved by providing the best age to perform preventive maintenance based on the history of the main machine and the subcontracting machine condition. Following these results, the authors of [114] have pursued the same context to deal with the same problem, but with two subcontractors differing in unit cost of production and availability. Initially, they proposed a strategy based on only one of the two subcontractors. They proved that the criteria for selecting the best subcontractor only concerned the unit cost of the lost demand. In the second step, they defined a policy of switching between the two subcontractors, starting with the least reliable and the cheapest, then switching to the other. The optimisation of this strategy was sequential. The first step was to determine the optimal age for preventive maintenance by minimising the average maintenance cost and then calculating the optimum switching date during the maintenance period by minimising production and shortage costs. In addition, other authors [115] have addressed a manufacturing problem for a production system that considered the return of the finished product. The aim was to establish an optimal production and maintenance plan while considering the production rate and the failure rate of the machine. In addition, reference [116] developed and optimised a new maintenance policy integrating the constraints of the subcontractor. They dealt with a case study that demonstrated the influence of the subcontractor's constraints on the optimal maintenance strategy adopted. Based on the results obtained, reference [117] also analysed the combined production and maintenance policies of a manufacturing system subjected to a subcontracting constraint. They studied analytically the problem of the integration of the subcontracting activity and the number of subcontracting tasks to be carried out during a maintenance cycle. They have assumed that production was governed by a common policy of maintenance 
management and production control. They were interested in the problem of unforeseen extensions in the duration of subcontracting. According to [117], the integration of maintenance into subcontracting production is a trade-off between production management and maintenance management and managing the production support in which several subcontracting companies differ by their availability and unit production costs. Also, reference [118] proposed a different optimal plan combined with a preventive maintenance policy aimed at reducing machine degradation while minimising the total cost including production, inventory and maintenance costs. They also proposed a model that simultaneously optimised a production plan and a maintenance policy by trying to find the optimum times for carrying out preventive maintenance actions and by defining the transferable quantity of the contractor's machine to its subcontractor counterparty. Concerning the determination of the optimal age $\mathrm{T}$ and the optimal stock, reference [119] put forward an analytical model in the context of a production system with an outsourcing option. This model allowed simultaneous determination of $\mathrm{T}$ and $\mathrm{S}$, minimising the average total cost including the cost of production, maintenance, lost orders and storage. Similarly, the authors of reference [120] studied a manufacturing system that used subcontracting to satisfy a random demand over a finite horizon. The aim was to find an optimal production plan that took account of subcontracting. Subsequently, reference [6] used outsourcing as an independent production system to meet a random demand. On the other hand, it considered a realistic case; the subcontractor can provide only a fixed amount throughout the horizon, by determining an optimal production plan considering the degradation of the machine and simultaneously minimising inventory, degradation and cost of production.

For their part, an analytical model has been proposed by [121] to optimise maintenance and production in a subcontracting context by integrating a stock to compensate for losses due to the unavailability of the ordering machine and the subcontractor. Recently, reference [122] proposed an integrated model that defined the structure of a common optimal policy for the interaction of production, quality, maintenance and subcontracting activities in a context of deterioration. Another model of subcontracting was presented by [7], which obtained an optimal production plan and a preventive maintenance program, the aim being to reduce the frequency of failure. Noncompliant products returned by customers were sent to a subcontractor for recycling to restore them in good condition. A work by [123] focused on combined production and maintenance plans for a manufacturing system, satisfying a random demand over a finite horizon. In their model, they assumed that the failure rate depended on time and production rate. Furthermore, the authors of reference [124] treated the adjustable capacity for an unreliable manufacturing system in which a standby machine was required to serve as a support to satisfy product demand if the inventory level fell below a specific threshold. Recently, the authors of reference [125] worked in the context of prediction problems with a subcontracting constraint. The objective was to determine the production plans for the main machine, as well as for the subcontractor machine. The purpose was to determine the exact time for carrying out preventive maintenance actions, history and production plan of the main machine, as well as the condition of the subcontractor machine. They developed two maintenance strategies: SMS (Simple Maintenance Strategy) and IMS (An Improved Maintenance Strategy) to increase the availability of the main machine and reduce maintenance costs. In another context, reference [126] addressed the problem of predicting production optimisation and maintenance under subcontracting constraint with transport delay. They proposed an analytical formulation of this problem to find an optimal production and maintenance 
plan. They determined an effective periodic preventive maintenance policy with minimum repair and an optimal production plan that integrated the various constraints for production rates, transport time and return deadline. Their proposed maintenance strategy was carried out to minimise the total maintenance cost to obtain the optimum number of preventive maintenance actions. Other authors [127] have addressed the problem of a dynamic cellular manufacturing system under dynamic environmental constraint and developed an integrated mathematical model of multi-period cell formation and production planning. The aim of the analytical analysis was to minimise the cost of reconfiguration, partial subcontracting, intra/cellular transfer and inventory by showing the impact of the compromise between production costs and outsourcing costs. Table 5 summarises some of the integrated maintenance models under subcontracting constraints, based on the study system, the decision parameters, the objective function and the method of resolution presented in the next section.

\section{Resolution Approaches}

The goal of an optimisation problem is to obtain the best result under the given circumstances. Optimisation consists of determining the extremums of a function, called the objective function in literature. The latter corresponds to an algebraic relation between one or more output variables of the studied system, called 'criteria'. The success of the optimisation procedure depends on the choice of the objective function and its functional relationship with the control parameters [128].

Certainly, the optimisation of the maintenance strategies consists of finding the optimal dates of preventive maintenance interventions while respecting the fixed objectives. In addition, to reduce production costs, planning tools and techniques should be adopted to align resources with demand and to optimise production capacity in line with the current business realities. To optimise the maintenance and the production in a simultaneous way, it is rather necessary to go towards a coupled algorithmic approach. The goal of an optimisation algorithm is to find a solution of a highly complex problem automatically and quickly. In this sense, several methods of resolution were developed. These methods can be summarised into two main families:

- The exact methods (complete) that guarantee a unique optimal solution. They provide optimum solutions for problems of reasonable size.

- The approach methods (incomplete) that lose completeness to improve efficiency. They are a very interesting alternative for dealing with large optimisation problems if optimality is not paramount. Figure 5 shows the set of algorithms used for optimisation to solve optimisation problems.

An integrated maintenance optimisation model is a mathematical model in which the costs and benefits of maintenance and production are quantified to achieve an optimal balance between both. Definitely, the methods of resolution and optimisation have been used more and more for a long time where taboo search methods and genetic algorithms can be cited [129-131]. Over the past decade, significant progress has been made with the emergence of a new generation of powerful and general approaches, often called metaheuristics $[132,133]$. Several approaches have been developed to solve the problem of planning and maintenance of joint production. Moreover, some mathematical propositions and properties have been suggested and applied in the proposed heuristic to solve this integrated problem based on the Lagrangian relaxation of the capacity constraints and the optimisation of the sub-gradient [35]. In addition, heuristics based on genetic algorithms have been used to solve an integrated optimisation model for production scheduling and preventive maintenance planning [61]. The optimisation of 
integrated maintenance is developed as a mathematical discipline in operational research. Hence, the choice of optimisation method impacts the decision-making regarding the strategy adopted.

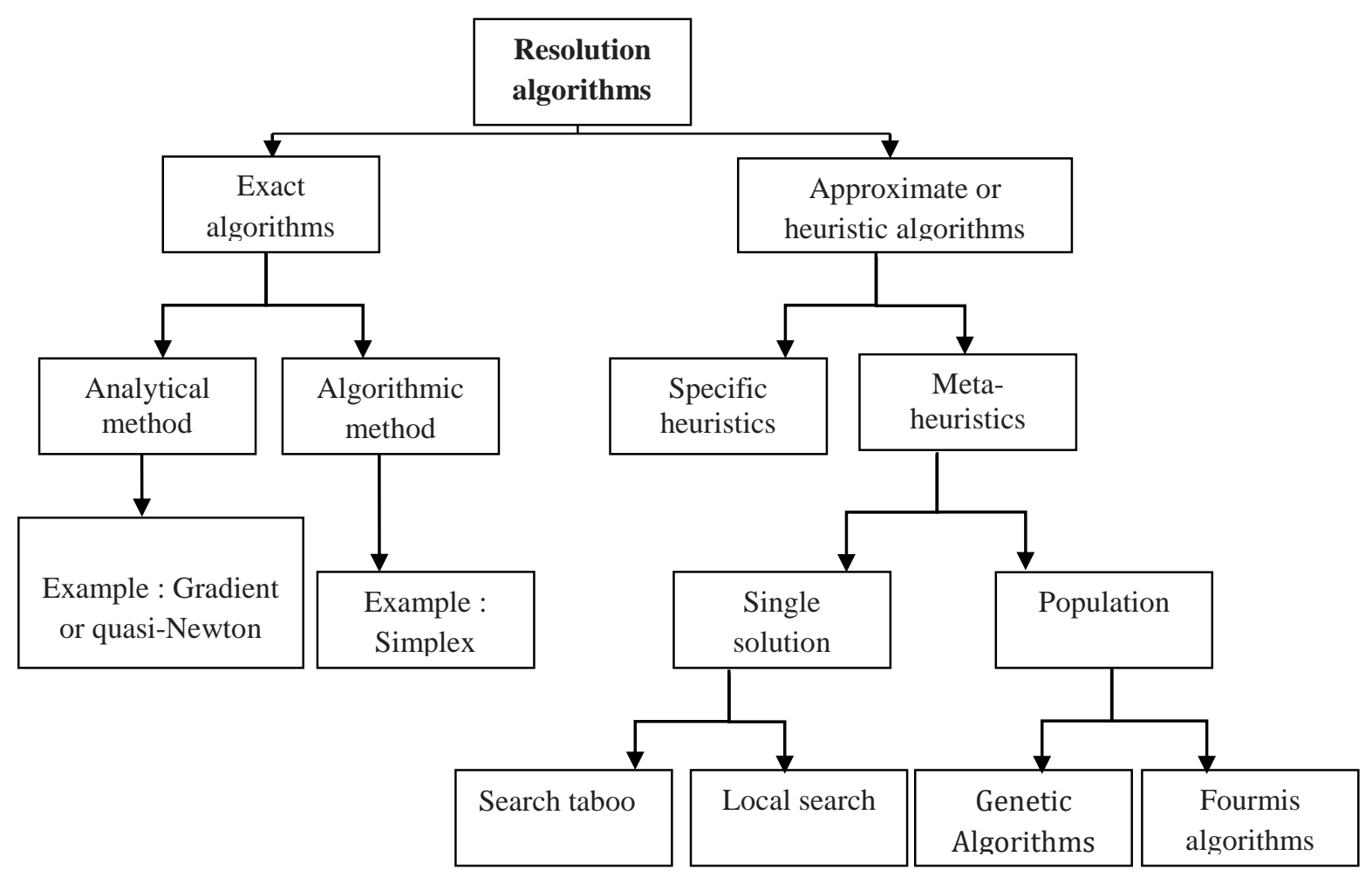

Figure 5. A classification of optimisation algorithms [134]

\section{RESULTS AND DISCUSSION}

Some published references are definitely missing in this work. Secondly, for reasons of clarity, a terminology covering all the current ratings has been opted, making it possible to identify the decision-making parameters of the integrated maintenance for production using subcontracting (Table 3). These settings are necessary for integrated problem optimisation. The analysis of the table of synthesis of the models of maintenance integrated with production under subcontracting constraint (Table 5) has made it possible to affirm that in most cases, the system of study consisted of two types of machines: manufacturer main machine $(\mathrm{M})$ and subcontractor machine (SM), concerning the differing decision parameters from one model to another. Generally, parameters and costs of maintenance/production of the manufacturer and those of the subcontractor were found. The objective function was frequently considered to be the total cost of the maintenance/production policy with the subcontracting constraint. These models made it possible to determine the stock level, the optimal age of preventive maintenance, the optimal production plan, and the choice of a subcontractor among several others based on different data.

In our research, we considered 24 references for integrated production maintenance using subcontracting of production systems, as well as the management of subcontracting production shown in Table 4. Figure 6 indicates the percentage of publication by the type of resolution method adopted. $58 \%$ of the references used the 
analytical resolution while $25 \%$ of the publications adopted the exact/approximate methods to optimise the objective function. The remaining $17 \%$ of publications represented the other types of optimisation methods. Obtaining an exact solution for such a hard problem in a reasonable time is hardly attainable. Thus, it is necessary to use a heuristic or meta-heuristic approach to solve joint optimisation models for real-size problems. In general, the optimisation methods employed included Markov decision methods, linear and nonlinear programming, decision analysis techniques and heuristic approaches.

Table 3. Decision parameters for hybrid management maintenance/production under subcontracting constraint

\begin{tabular}{|c|c|c|c|}
\hline Settings & Significations & Settings & Significations \\
\hline$U_{\max }$ & $\begin{array}{l}\text { Maximum production rate of } \\
\text { a machine } \mathrm{M}\end{array}$ & $C_{h}$ & Unit cost of holding \\
\hline$C_{M}$ & $\begin{array}{l}\text { Unit cost of production of a } \\
\text { machine } \mathrm{M}\end{array}$ & $C_{S}$ & Unit cost of shortage \\
\hline$C_{S M}$ & $\begin{array}{l}\text { Unit cost of production of a } \\
\text { machine SM }\end{array}$ & $T D$ & $\begin{array}{l}\text { Delay in transport of urgent } \\
\text { subcontracting }\end{array}$ \\
\hline$P_{M}$ & Production rate of $\mathrm{M}$ & $P_{S M}$ & SM machine production rate \\
\hline$T_{S M}$ & Machine SM availability rate & $B$ & $\begin{array}{l}\text { Service level of the machine } \\
\text { SM }\end{array}$ \\
\hline$D$ & Demand quantity & $T_{V}$ & Inventory level \\
\hline$F$ & $\begin{array}{l}\text { Fault failure rate of machine } \\
M\end{array}$ & $C_{p}$ & $\begin{array}{l}\text { Preventive maintenance action } \\
\text { cost }\end{array}$ \\
\hline$C_{D M}$ & $\begin{array}{l}\text { Cost of degradation of } \\
\text { machine M }\end{array}$ & $C_{c}$ & $\begin{array}{l}\text { Cost of Corrective } \\
\text { Maintenance Action } \\
\text { Number of preventive }\end{array}$ \\
\hline$M T B F$ & Mean time between failures & $N$ & $\begin{array}{l}\text { maintenance actions of } \\
\text { machine } \mathrm{M}\end{array}$ \\
\hline MTTR & Mean time to repair & $T_{p}$ & $\begin{array}{l}\text { Average preventive } \\
\text { maintenance action time of } \\
\text { machine } \mathrm{M}\end{array}$ \\
\hline$U_{\max S M}$ & $\begin{array}{l}\text { Maximum production rate of } \\
\text { the subcontractor }\end{array}$ & $T_{c M}$ & $\begin{array}{l}\text { Average corrective } \\
\text { maintenance action time of } \\
\text { machine } \mathrm{M}\end{array}$ \\
\hline$U_{\min S M}$ & $\begin{array}{l}\text { Minimum production rate of } \\
\text { the subcontractor }\end{array}$ & $T_{c S M}$ & $\begin{array}{l}\text { Average corrective } \\
\text { maintenance action time of } \\
\text { machine SM }\end{array}$ \\
\hline
\end{tabular}

In general, the integrated works aimed at achieving an optimal maintenance strategy as well as an economical production plan by constructing a production plan that respects the dates of preventive maintenance intervention. In planning maintenance tasks, different planning policies can be implemented. Some authors proposed to perform maintenance tasks during the scheduled shutdowns of production machines by planning and determining a schedule of maintenance interventions and production operations in a joint manner. Others integrated maintenance into production, determining the optimal buffer size and age of preventive maintenance in a sequential way; beyond this, the coupling between production and maintenance at the management level. 
Integration of maintenance and production strategies under subcontracting constraint: classification and opportunity

Table 4. Synthesis of resolution approaches

\begin{tabular}{cl}
\hline Reference & \multicolumn{1}{c}{ Approach } \\
\hline$[107]$ & Heuristic \\
{$[108]$} & Combined approach between experimental design, variance \\
& analysis, response surface methodology and simulation modelling. \\
{$[109]$} & Analytical study \\
{$[110]$} & Genetic algorithms \\
{$[112]$} & Analytical study \\
{$[113]$} & Analytical study \\
{$[114]$} & Analytical study \\
{$[116]$} & Analytical study \\
{$[117]$} & Analytical study \\
{$[117]$} & Analytical study \\
{$[118]$} & Analytical study \\
{$[119]$} & Analytical study \\
{$[120]$} & PA: Perturbation Analysis \\
{$[6]$} & FPA: Finite Perturbation Analysis \\
{$[121]$} & Analytical study \\
{$[122]$} & Dynamic programming \\
{$[7]$} & Stochastic quadratic linear optimisation \\
{$[123]$} & Analytical study \\
{$[124]$} & Dynamic programming \\
{$[125]$} & Analytical study \\
{$[126]$} & Analytical study \\
{$[135]$} & Analytical study \\
{$[136]$} & Genetic algorithms \\
{$[98]$} & Heuristic \\
\hline &
\end{tabular}

One study has chosen to deal with the third axis of quality concerning the models of the maintenance integrated to the production under the constraint of subcontracting. The main objective was to find a compromise between joint maintenance/production and subcontracting by optimising the total cost, since subcontracting of production made it possible to satisfy the customers' needs in terms of time and quantity. The disadvantage of these models was that they dealt with specific cases at the level of the study system, decision parameters and objective functions, which cannot be generalised and applied to other problems.

This review also suggests some avenues for future research. With the dominance of globalisation and the concept of open markets, most factories produce different types of products for different markets. The price of these products becomes a problem and must be linked to the cost of production, maintenance and quality. Logistics can be included in the integrated maintenance. Integrated models can also be studied for the subcontracting of maintenance alongside the subcontracting of production. Therefore, it is necessary to make a change in the company's culture regarding the management of maintenance and production in a joint by adopting outsourcing as a solution that satisfies the customer's need in terms of quantity and time. Hence, slandering modern tools for managing maintenance integrated with production using subcontracting is important. 
Table 5. Synthesis of integrated maintenance models for subcontracting production.

\begin{tabular}{|c|c|c|c|c|}
\hline Reference & Settings & Objective function & Achievements & $\begin{array}{l}\text { Method of } \\
\text { resolution }\end{array}$ \\
\hline [114] & $\begin{array}{l}C_{c}, C_{p}, C_{S M} \\
C_{M}, C_{s}, T_{S M} \\
F\end{array}$ & $\begin{array}{l}\text { Average total cost } \\
\text { including maintenance, } \\
\text { production and loss of } \\
\text { demand. }\end{array}$ & $\begin{array}{l}\text {-Choice of a subcontractor } \\
\text { between } \\
\text { subcontractors. } \\
\text {-Optimal date for preventive } \\
\text { maintenance machine M. } \\
\text { - Switching strategy between } \\
\text { subcontractors. }\end{array}$ & $\begin{array}{l}\text { Analytical } \\
\text { resolution }\end{array}$ \\
\hline [119] & $\begin{array}{l}C_{c}, C_{p}, C_{S M} \\
C_{M}, U_{\max } \\
B \\
C_{S}, T_{S M}, \quad T_{V}\end{array}$ & $\begin{array}{l}\text { Average total cost per } \\
\text { unit of time, regrouping } \\
\text { preventive maintenance } \\
\text { actions, production, } \\
\text { inventory and } \\
\text { degradation of the } \\
\text { machine M. }\end{array}$ & $\begin{array}{l}\text {-Determining an optimal } \\
\text { production plan. } \\
\text {-Determine the optimal stock } \\
\text { level. } \\
\text {-The quantity to be } \\
\text { subcontracted. } \\
\text {-Optimal Age of Preventive } \\
\text { Maintenance. }\end{array}$ & $\begin{array}{l}\text { Analytical } \\
\text { resolution }\end{array}$ \\
\hline [6] & $\begin{array}{l}B, F, C_{S M}, \\
C_{M}, T_{S M} \\
U_{\max }, P_{M}, \\
P_{S M}, U_{\min S M}\end{array}$ & $\begin{array}{l}\text {-Number of preventive } \\
\text { maintenance action. } \\
\text {-Cost production } \\
\text { according } \\
\text { availability. }\end{array}$ & $\begin{array}{l}\text {-Determine a production plan. } \\
\text {-The optimum production } \\
\text { rate of the two manufacturing } \\
\text { systems of machines } M \text { and } \\
\text { SM. } \\
\text {-The number of preventive } \\
\text { maintenance actions of the } \\
\text { machine M. }\end{array}$ & $\begin{array}{l}\text { FPA: Finite } \\
\text { Perturbation } \\
\text { Analysis }\end{array}$ \\
\hline$[124]$ & $\begin{array}{l}U_{\max }, P_{M}, \\
P_{S M}, C_{C}, C_{p} \\
C_{S M}, C_{M}, C_{D M}\end{array}$ & $\begin{array}{l}\text {-Total production cost. } \\
\text {-Total maintenance } \\
\text { cost. }\end{array}$ & $\begin{array}{l}\text {-Establish an optimal } \\
\text { production plan. } \\
\text {-Establish an optimal } \\
\text { maintenance plan minimising } \\
\text { the total cost of maintenance }\end{array}$ & $\begin{array}{l}\text { Analytical } \\
\text { resolution }\end{array}$ \\
\hline [108] & $\begin{array}{l}T_{V}, P_{M}, P_{S M}, \\
U_{\max } \\
M T B F \\
M T T R, C_{S M}, \\
C_{M}, T D\end{array}$ & $\begin{array}{l}\text { The total cost incurred } \\
\text { while respecting the } \\
\text { constraints of the client. }\end{array}$ & $\begin{array}{l}\text { Determine optimal control } \\
\text { parameter values that } \\
\text { minimise the total cost } \\
\text { incurred. }\end{array}$ & $\begin{array}{l}\text { Combined } \\
\text { approach } \\
\text { between } \\
\text { experimental } \\
\text { design, } \\
\text { variance } \\
\text { analysis, } \\
\text { response } \\
\text { surface } \\
\text { methodology } \\
\text { and } \\
\text { simulation } \\
\text { modelling. }\end{array}$ \\
\hline [135] & $\begin{array}{l}C_{P}, C_{C}, C_{p u} \\
U_{\max }, d, T_{p} \\
T_{c M}, T_{c S M}\end{array}$ & $\begin{array}{l}\text { The total average cost of } \\
\text { the } \\
\text { maintenance/production } \\
\text { policy. }\end{array}$ & $\begin{array}{l}\text {-Determine the optimal age of } \\
\text { preventive maintenance. } \\
\text {-Determine optimal stock } \\
\text { level and total maintenance } \\
\text { cost }\end{array}$ & $\begin{array}{l}\text { Analytical } \\
\text { resolution }\end{array}$ \\
\hline [110] & $\begin{array}{l}T_{V}, C_{h}, C_{S}, \\
C_{P}, C_{C}, P_{S M} \\
, \quad U_{\min S M}, \\
U_{\max S M}\end{array}$ & $\begin{array}{l}\text { The total estimated cost } \\
\text { includes the costs of } \\
\text { production, holding, } \\
\text { maintenance, shortage } \\
\text { and subcontracting. }\end{array}$ & $\begin{array}{l}\text {-Determining optimal internal } \\
\text { production. } \\
\text { - Subcontracting rates. }\end{array}$ & $\begin{array}{l}\text { Genetic } \\
\text { algorithms }\end{array}$ \\
\hline
\end{tabular}

Our future work aims to develop new integrated maintenance-production models in the context of outsourcing by offering manufacturers new strategies through which it 
would be possible for them to simultaneously process the parameters of production and those of maintenance in accordance with customer requirements. Moreover, we plan in the next work to add the constraints related to the cost of quality by using an analytical resolution. The model will be simulated later in order to evaluate its effectiveness.

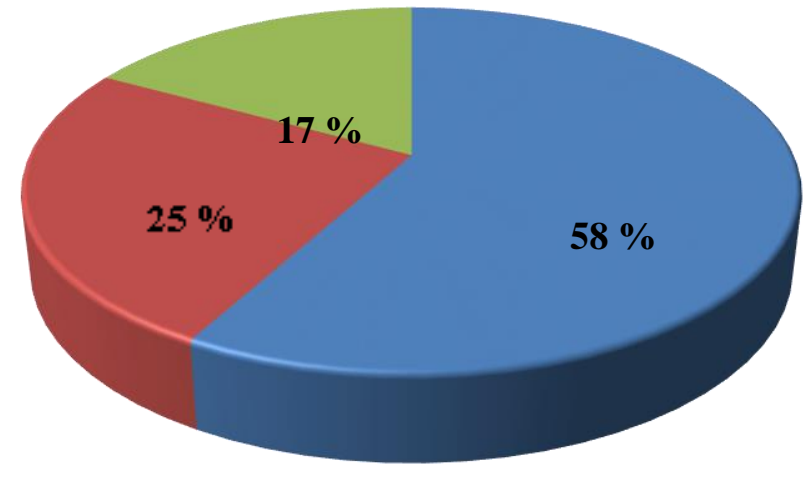

Analytical resolution

Exact / Approach Method

四Other

Figure 6. Percentage of publication by type of resolution method adopted.

\section{CONCLUSIONS}

This article highlights the integrated maintenance of a production system with the objective of satisfying customer demand that is higher than its maximum production capacity by using outsourcing. Initially, the integrated maintenance/production models were presented by outlining the approaches adopted. Then, the models of integrated maintenance under subcontracting constraint were synthesised using the system studied, the decision parameters, the objective function and the set of optimisations used. This work analysed more than 100 references related to maintenance management integrated into the production system with a subcontracting constraint in relevant operational research and management reviews. To study the work analysed, a classification was proposed based on the analysis of the following aspects: separate management, integrated management, subcontracting constraints, modelling approach, optimisation approach, development tool, limits and benefits.

Finally, the interaction between modelling and algorithms will play an important role in future research. The inclusion of industrial concerns leads to larger and more complex models and therefore more complex algorithms are needed to solve them. Solution approaches for integrated models will be based on previous research and on separate models. In this perspective, on the one hand, our research will lead us to find a compromise between the maintenance management and the production management, and on the other hand, the subcontracting services offered by the company, guaranteeing firstly the internal stability of the company and the evolution of its profits while proposing the implementation of feasible models and tools capable of prescribing the best maintenance policy in the case of production under the constraint of subcontracting.

\section{ACKNOWLEDGEMENTS}

The authors would like to thank the editors and anonymous reviewers for their useful comments and their constructive suggestions, which helped to improve this paper under project no. JMES1707225, in order to make it appropriate for publication in Journal of mechanical Engineering and Sciences. 


\section{REFERENCES}

[1] Mifdal L, Hajej Z, Dellagi S. Joint Optimization Approach of Maintenance and Production Planning for a Multiple-Product Manufacturing System. Mathematical Problems in Engineering. 2015;2015:1-17.

[2] Hadidi LA, Turki UMA, Rahim A. Integrated models in production planning and scheduling, maintenance and quality: a review. International Journal of Industrial and Systems Engineering. 2012;10:21.

[3] Zied H, Sofiene D, Nidhal R. An optimal maintenance planning according to production rate satisfying random demand. In: Control and Fault-Tolerant Systems (SysTol), 2010 Conference on; 2010. p. 418-23.

[4] Aramon Bajestani M, Banjevic D, Beck JC. Integrated maintenance planning and production scheduling with Markovian deteriorating machine conditions. International Journal of Production Research. 2014;52:7377-400.

[5] Dehayem Nodem FI, Kenné JP, Gharbi A. Simultaneous control of production, repair/replacement and preventive maintenance of deteriorating manufacturing systems. International Journal of Production Economics. 2011;134:271-82.

[6] Ayed S, Hajej Z, Turki S, Rezg N. FPA method for optimal production planning under availability/degradation machine and subcontracting constraint. International Journal of Production Research. 2017;55:2135-48.

[7] Zied H, Sofiene D, Nidhal R. Joint optimisation of maintenance and production policies with subcontracting and product returns. Journal of Intelligent Manufacturing. 2014:1-14.

[8] Mohamed NMZN, Khan MK. Decomposition of Manufacturing Processes: A Review. International Journal of Automotive and Mechanical Engineering. 2012;5:545-60.

[9] Shahin A. The relationship between quality and productivity: a new perspective. International Journal of Productivity and Quality Management. 2008;3:206.

[10] Buzacott JA, Shanthikumar JG. Stochastic models of manufacturing systems. Englewood Cliffs, N.J: Prentice Hall; 1993.

[11] Dallery Y, Gershwin SB. Manufacturing flow line systems: a review of models and analytical results. Queueing Systems. 1992;12:3-94.

[12] Xie X. Performance analysis of a transfer line with unreliable machines and finite buffers. IIE Transactions. 1993;25:99-108.

[13] Van der Duyn Schouten FA, Vanneste SG. Maintenance optimization of a production system with buffer capacity. European Journal of Operational Research. 1995;82:323-38.

[14] Meller RD, Kim DS. The impact of preventive maintenance on system cost and buffer size. European Journal of Operational Research. 1996;95:577-91.

[15] Mansor MA, Ohsato A, Sulaiman S. Knowledge Management for Maintenance Activities in the Manufacturing Sector. International Journal of Automotive and Mechanical Engineering. 2012;5:612-21.

[16] Andrew-Munot M, Ibrahim RN. Remanufacturing Process and Its Challenges. Journal of Mechanical Engineering and Sciences. 2013;4:488-95.

[17] Kenne JP, Boukas EK, Gharbi A. Control of production and corrective maintenance rates in a multiple-machine, multiple-product manufacturing system. Mathematical and Computer Modelling. 2003;38:351-65. 
[18] Gharbi A, Kenne JP. Production and preventive maintenance rates control for a manufacturing system: An experimental design approach. International Journal of Production Economics. 2000;65:275-87.

[19] Bergeron D, Jamali MA, Ait-Kadi D. Coupling Simulation and Optimization for an Integrated Production and Maintenance Planning in Manufacturing Systems. IFAC Proceedings Volumes. 2009;42:1091-5.

[20] Kenné JP, Boukas EK. Hierarchical control of production and maintenance rates in manufacturing systems. Journal of Quality in Maintenance Engineering. 2003;9:66-82.

[21] Kenné JP, Gharbi A. Stohastic optimal production control problem with corrective maintenance. Computers \& Industrial Engineering. 2004;46:865-75.

[22] Gharbi A, Kenné J-P. Maintenance scheduling and production control of multiplemachine manufacturing systems. Computers \& Industrial Engineering. 2005;48:693-707.

[23] Charlot E, Kenné JP, Nadeau S. Optimal production, maintenance and lockout/tagout control policies in manufacturing systems. International Journal of Production Economics. 2007;107:435-50.

[24] Kenne JP, Nkeungoue LJ. Simultaneous control of production, preventive and corrective maintenance rates of a failure-prone manufacturing system. Applied Numerical Mathematics. 2008;58:180-94.

[25] Ben-Salem A, Gharbi A, Hajji A. Environmental issue in an alternative production-maintenance control for unreliable manufacturing system subject to degradation. The International Journal of Advanced Manufacturing Technology. 2015;77:383-98.

[26] OUALI M-S, REZG N, XIAOLAN X. Maintenance préventive et optimisation des flux d'un système de production. Journal européen des systèmes automatisés. 2002;36:97-116.

[27] Yalaoui A, Chaabi K, Yalaoui F. Integrated production planning and preventive maintenance in deteriorating production systems. Information Sciences. 2014;278:841-61.

[28] Roux O, Duvivier D, Quesnel G, Ramat E. Optimization of preventive maintenance through a combined maintenance-production simulation model. International Journal of Production Economics. 2013;143:3-12.

[29] Zied H, Sofiene D, Nidhal R. An optimal production/maintenance planning under stochastic random demand, service level and failure rate. In: Automation Science and Engineering, 2009 CASE 2009 IEEE International Conference on; 2009. p. 292-7.

[30] Zied H, Sofiene D, Nidhal R. Optimal integrated maintenance/production policy for randomly failing systems with variable failure rate. International Journal of Production Research. 2011;49:5695-712.

[31] Benbouzid Sitayeb F. Contribution à l'étude de la performance et de la robustesse des ordonnancements conjoints production/maintenance: cas du flowshop: Besançon; 2005.

[32] Fitouhi M-C, Nourelfath M. Integrating noncyclical preventive maintenance scheduling and production planning for multi-state systems. Reliability Engineering \& System Safety. 2014;121:175-86.

[33] Bouslah B, Gharbi A, Pellerin R. Joint optimal lot sizing and production control policy in an unreliable and imperfect manufacturing system. International Journal of Production Economics. 2013;144:143-56. 
[34] Cheng GQ, Zhou BH, Li L. Joint optimisation of production rate and preventive maintenance in machining systems. International Journal of Production Research. 2016;54:6378-94.

[35] Alaoui-Selsouli M, Mohafid A, Najid NM. Lagrangian relaxation based heuristic for an integrated production and maintenance planning problem. International Journal of Production Research. 2012;50:3630-42.

[36] Aghezzaf EH, Jamali MA, Ait-Kadi D. An integrated production and preventive maintenance planning model. European Journal of Operational Research. 2007;181:679-85.

[37] Xiang Y, Cassady CR, Jin T, Zhang CW. Joint production and maintenance planning with machine deterioration and random yield. International Journal of Production Research. 2014;52:1644-57.

[38] Bennour M, Bloch C, Zerhouni N. Modélisation intégrée des activités de maintenance et de production. In: 3e Conférence Francophone de Modélisation et de SIMulation MOSIM'01; 2001. p. 805-10.

[39] Najid NM, Alaoui-Selsouli M, Mohafid A. An integrated production and maintenance planning model with time windows and shortage cost. International Journal of Production Research. 2011;49:2265-83.

[40] Salameh MK, Ghattas RE. Optimal just-in-time buffer inventory for regular preventive maintenance. International Journal of Production Economics. 2001;74:157-61.

[41] El-Kassar A, Salameh M. Safety Butter for Preventive maintenance and Breakdown. Porto, Portugal; 2003.

[42] Rezg N, Xie X, Mati Y. Joint optimization of preventive maintenance and inventory control in a production line using simulation. International Journal of Production Research. 2004;42:2029-46.

[43] Chelbi A, Ait-Kadi D. Analysis of a production/inventory system with randomly failing production unit submitted to regular preventive maintenance. European Journal of Operational Research. 2004;156:712-8.

[44] Kenné J-P, Gharbi A, Beit M. Age-dependent production planning and maintenance strategies in unreliable manufacturing systems with lost sale. European Journal of Operational Research. 2007;178:408-20.

[45] Srinivasan MM, Lee H-S. Production-Inventory Systems with Preventive Maintenance. IIE Transactions. 1996;28:879-90.

[46] Weinstein L, Chung C-H. Integrating maintenance and production decisions in a hierarchical production planning environment. Computers \& Operations Research. 1999;26:1059-74.

[47] Yao X, Xie X, Fu MC, Marcus SI. Optimal joint preventive maintenance and production policies. Naval Research Logistics. 2005;52:668-81.

[48] Iravani SMR, Duenyas I. Integrated maintenance and production control of a deteriorating production system. IIE Transactions. 2002;34:423-35.

[49] Gharbi A, Kenné J-P, Beit M. Optimal safety stocks and preventive maintenance periods in unreliable manufacturing systems. International Journal of Production Economics. 2007;107:422-34.

[50] Liao G-L. Optimal production correction and maintenance policy for imperfect process. European Journal of Operational Research. 2007;182:1140-9.

[51] Berthaut F, Gharbi A, Kenné J-P, Boulet J-F. Improved joint preventive maintenance and hedging point policy. International Journal of Production Economics. 2010;127:60-72. 
[52] Brandolese M, Franci M, Pozzetti* A. Production and maintenance integrated planning. International Journal of Production Research. 1996;34:2059-75.

[53] Cassady CR, Kutanoglu E. Minimizing Job Tardiness Using Integrated Preventive Maintenance Planning and Production Scheduling. IIE Transactions. 2003;35:503-13.

[54] Pandey D, Kulkarni MS, Vrat P. A methodology for joint optimization for maintenance planning, process quality and production scheduling. Computers \& Industrial Engineering. 2011;61:1098-106.

[55] Hadidi LA, Turki UMA, Rahim MA. An integrated cost model for production scheduling and perfect maintenance. International Journal of Mathematics in Operational Research. 2011;3:395.

[56] Hnaien F, Yalaoui F, Mhadhbi A, Nourelfath M. A mixed-integer programming model for integrated production and maintenance. IFAC-PapersOnLine. 2016;49:556-61.

[57] Sortrakul N, Nachtmann HL, Cassady CR. Genetic algorithms for integrated preventive maintenance planning and production scheduling for a single machine. Computers in Industry. 2005;56:161-8.

[58] Ramirez Restrepo LM, Hennequin S, Aguezzoul A. Optimization of integrated preventive maintenance based on infinitesimal perturbation analysis. Computers \& Industrial Engineering. 2016;98:470-82.

[59] Wang S, Liu M. A branch and bound algorithm for single-machine production scheduling integrated with preventive maintenance planning. International Journal of Production Research. 2013;51:847-68.

[60] Berthaut F, Gharbi A, Dhouib K. Joint modified block replacement and production/inventory control policy for a failure-prone manufacturing cell. Omega. 2011;39:642-54.

[61] Cassady CR, Kutanoglu E. Integrating Preventive Maintenance Planning and Production Scheduling for a Single Machine. IEEE Transactions on Reliability. 2005;54:304-9.

[62] Cui W-W, Lu Z, Pan E. Integrated production scheduling and maintenance policy for robustness in a single machine. Computers \& Operations Research. 2014;47:81-91.

[63] Sortrakul N, Cassady CR. Genetic algorithms for total weighted expected tardiness integrated preventive maintenance planning and production scheduling for a single machine. Journal of Quality in Maintenance Engineering. 2007;13:4961.

[64] Mehdi R, Nidhal R, Anis C. Integrated maintenance and control policy based on quality control. Computers \& Industrial Engineering. 2010;58:443-51.

[65] Yulan J, Zuhua J, Wenrui H. Multi-objective integrated optimization research on preventive maintenance planning and production scheduling for a single machine. The International Journal of Advanced Manufacturing Technology. 2008;39:95464.

[66] Lu Z, Cui W, Han X. Integrated production and preventive maintenance scheduling for a single machine with failure uncertainty. Computers \& Industrial Engineering. 2015;80:236-44.

[67] Berrichi A, Amodeo L, Yalaoui F, Châtelet E, Mezghiche M. Bi-objective optimization algorithms for joint production and maintenance scheduling: application to the parallel machine problem. Journal of Intelligent Manufacturing. 2009;20:389-400. 
[68] Nourelfath M, Châtelet E. Integrating production, inventory and maintenance planning for a parallel system with dependent components. Reliability Engineering \& System Safety. 2012;101:59-66.

[69] Nourelfath M, Nahas N, Ben-Daya M. Integrated preventive maintenance and production decisions for imperfect processes. Reliability Engineering \& System Safety. 2016;148:21-31.

[70] Gouiaa-Mtibaa A, Dellagi S, Achour Z, Erray W. Integrated Maintenance-Quality strategies with reworking activities. IFAC-PapersOnLine. 2016;49:61-6.

[71] Ben-Daya M, Duffuaa S. Maintenance and quality: the missing link. Journal of Quality in Maintenance Engineering. 1995;1:20-6.

[72] Ben-Daya M, Makhdoum M. Integrated Production and Quality Model under Various Preventive Maintenance Policies. The Journal of the Operational Research Society. 1998;49:840.

[73] Bouslah B, Gharbi A, Pellerin R. Integrated production, sampling quality control and maintenance of deteriorating production systems with AOQL constraint. Omega. 2016;61:110-26.

[74] Colledani M, Tolio T. Integrated quality, production logistics and maintenance analysis of multi-stage asynchronous manufacturing systems with degrading machines. CIRP Annals. 2012;61:455-8.

[75] Pandey D, Kulkarni MS, Vrat P. Joint consideration of production scheduling, maintenance and quality policies: a review and conceptual framework. International Journal of Advanced Operations Management. 2010;2:1-24.

[76] Abdulnour G, Dudek RA, Smith ML. Effect of maintenance policies on the justin-time production system. International Journal of Production Research. 1995;33:565-83.

[77] Groenevelt H, Pintelon L, Seidmann A. Production Batching with Machine Breakdowns and Safety Stocks. Operations Research. 1992;40:959-71.

[78] Makis V, Fung J. Optimal preventive replacement, lot sizing and inspection policy for a deteriorating production system. Journal of Quality in Maintenance Engineering. 1995;1:41-55.

[79] Chung K-J. Approximations to production lot sizing with machine breakdowns. Computers \& Operations Research. 2003;30:1499-507.

[80] Wang C-H, Sheu SH. Determining the optimal production-maintenance policy with inspection errors: using a Markov chain. Computers \& Operations Research. 2003;30:1-17.

[81] Budai G, Dekker R, Nicolai RP. A review of planning models for maintenance and production. Economic Institute report. 2006:2006-44.

[82] Chelbi A, Rezg N. Analysis of a production/inventory system with randomly failing production unit subjected to a minimum required availability level. International Journal of Production Economics. 2006;99:131-43.

[83] Chelbi A, Aït-Kadi D. Joint Optimal Buffer Inventory and Preventive Maintenance Strategy for a Randomly Failing Production Unit. Journal of Decision Systems. 2003;12:21-30.

[84] Ben-Daya M. Integrated production maintenance and quality model for imperfect processes. IIE Transactions. 1999;31:491-501.

[85] Ben-Daya M. The economic production lot-sizing problem with imperfect production processes and imperfect maintenance. International Journal of Production Economics. 2002;76:257-64. 
[86] Colledani M, Ebrahimi D, Tolio T. Integrated quality and production logistics modelling for the design of selective and adaptive assembly systems. CIRP Annals. 2014;63:453-6.

[87] Cagliano R, Spina G. A comparison of practice-performance models between small manufacturers and subcontractors. International Journal of Operations \& Production Management. 2002;22:1367-88.

[88] Chaillou B. Définition et typologie de la sous-traitance. Revue économique. 1977:262-85.

[89] Amesse F, Dragoste L, Nollet J, Ponce S. Issues on partnering: evidences from subcontracting in aeronautics. Technovation. 2001;21:559-69.

[90] Seillan H, Morvan J. Risques de la sous-traitance: Éd." Préventique; 2005.

[91] Bandyopadhyay S, Pathak P. Knowledge sharing and cooperation in outsourcing projects - A game theoretic analysis. Decision Support Systems. 2007;43:34958.

[92] Genthon V. La sous-traitance industrielle: un phénomène en croissance. Le 4 pages des Statistiques Industrielles. 2000;131.

[93] Hery M. Besoins de recherches en santé sécurité du travail pour les salariés de la sous-traitance interne. Pistes. 2002;4:11.

[94] Gorgeu A, Mathieu R. Dix ans de relations de sous-traitance dans l'industrie française. Travail. 1993;28:23-44.

[95] Doniol-Shaw G. Sous-traitance et maintenance des centrales nucléaires. Travail. 1993;28:53-64.

[96] Grusenmeyer C. Sous-traitance et accidents. Exploitation de la base de données EPICEA. INRS; 2007.

[97] Andersen PH. Organizing international technological collaboration in subcontractor relationships: an investigation of the knowledge-stickiness problem. Research Policy. 1999;28:625-42.

[98] Bertrand JWM, Sridharan V. A study of simple rules for subcontracting in maketo-order manufacturing. European Journal of Operational Research. 2001;128:509-31.

[99] Berry A. SME competitiveness: the power of networking and subcontracting. Inter-American Development Bank; 1997.

[100] Andersen PH, Christensen PR. Inter-partner learning in global supply chains: lessons from NOVO Nordisk. European Journal of Purchasing \& Supply Management. 2000;6:105-16.

[101] Gomes-Casseres B. Group versus group: How alliance networks compete. Harvard business review. 1994;72:62-6.

[102] ICSI. À quoi faut-il penser, vis-à-vis de la sécurité, avant la décision éventuelle de sous-traiter? Toulouse, France: Cahiers de la Sécurité Industrielle, Institute for an Industrial Safety Culture; 2008.

[103] Bravard J-L, Morgan R. Smarter outsourcing: An executive guide to understanding, planning and exploiting successful outsourcing relationships: Pearson Education; 2006.

[104] Barthélemy J. Stratégies d'externalisation: Préparer, décider et mettre en oeuvre l'externalisation d'activités stratégiques: Dunod; 2007.

[105] Thébaud-Mony A. Travailler peut nuire gravement à la santé. Paris, La Découverte. 2007. 
[106] Tazi D. Externalisation de la maintenance et sécurité: une analyse bibliographique. Rapport technique, Institut pour une Culture de Sécurité Industrielle. 2010.

[107] Dror M, Smith KR, Yano CA. Deux Chemicals Inc. Goes Just-in-Time. Interfaces. 2009;39:503-15.

[108] Assid M, Gharbi A, Dhouib K. Joint production and subcontracting planning of unreliable multi-facility multi-product production systems. Omega. 2015;50:5469.

[109] Chouikhi H, Dellagi S, Rezg N. Development and optimisation of a maintenance policy under environmental constraints. International Journal of Production Research. 2012;50:3612-20.

[110] Haoues M, Dahane M, Mouss NK, Rezg N. Integrated Optimisation of In-House Production and Outsourcing Strategy: Genetic Algorithm Based Approach. IFAC Proceedings Volumes. 2013;46:420-5.

[111] Suppen N, Onosato M, Iwata K. A life-cycle maintenance methodology with environmental, health and safety considerations. 1999. p. 875-9.

[112] Dellagi S, Rezg N. Production/maintenance policies optimization in a subcontractor environment. Alexandria Egypt; 2007. p. 178-89.

[113] Dellagi S, Rezg N, Xie X. Preventive maintenance of manufacturing systems under environmental constraints. International Journal of Production Research. 2007;45:1233-54.

[114] Dellagi S, Rezg N, Gharbi A. Optimal maintenance/production policy for a manufacturing system subjected to random failure and calling upon several subcontractors. international journal of management science and engineering management. 2010;5:261-7.

[115] Ayed S, Dellagi S, Rezg N. Développement et optimisation d'une stratégie de maintenance dépendante du plan de production et tenant compte de droit rétractation. 8ème Conférence Internationale de Modélisation et de SimulationMOSIM 20102010.

[116] Dahane M, Clementz C, Rezg N. Analysis of joint maintenance and production policies under a subcontracting constraint. International Journal of Production Research. 2008;46:5393-416.

[117] Ayed S, Dellagi S, Rezg N. Optimal integrated maintenance production strategy with variable production rate for random demand and subcontracting constraint. IFAC Proceedings Volumes. 2011;44:5207-12.

[118] Ayed S, Sofiene D, Nidhal R. Joint optimisation of maintenance and production policies considering random demand and variable production rate. International Journal of Production Research. 2012;50:6870-85.

[119] Ayed S, Dellagi S, Rezg N. Optimisation d'une politique de maintenance intégrée sous une contrainte de sous-traitance avec contribution de stock. In: 8ème Conférence Internationale de Modélisation et de Simulation-MOSIM 2010; 2010.

[120] Souheil A, Sadok T, Zied H. Perturbation Analysis for Optimal Production Planning Of a Manufacturing System with Subcontracting and Machine Degradation. IFAC-PapersOnLine. 2015;48:2145-52.

[121] Cormier G, Rezg N. Analytical contributions to the joint optimization of maintenance, production and subcontracting. In: International Conference on Industrial Engineering and Systems Management IESM; 2009. p. 13-5.

[122] Rivera-Gómez H, Gharbi A, Kenné J-P, Montaño-Arango O, Hernandez-Gress ES. Production control problem integrating overhaul and subcontracting strategies 
for a quality deteriorating manufacturing system. International Journal of Production Economics. 2016;171:134-50.

[123] Zied H, Sofiene D, Nidhal R. Production/maintenance policies optimization with operational age concept in a subcontracting constraint. IFAC Proceedings Volumes. 2011;44:5213-8.

[124] Gharbi A, Hajji A, Dhouib K. Production rate control of an unreliable manufacturing cell with adjustable capacity. International Journal of Production Research. 2011;49:6539-57.

[125] Hajej Z, Rezg N, Gharbi A. Improved preventive maintenance in the framework of forecasting problem under subcontractor constraint. International Journal of Production Research. 2017;55:4557-600.

[126] Hajej Z, Rezg N, Gharbi A. Forecasting and maintenance problem under subcontracting constraint with transportation delay. International Journal of Production Research. 2014;52:6695-716.

[127] Safaei N, Tavakkoli-Moghaddam R. Integrated multi-period cell formation and subcontracting production planning in dynamic cellular manufacturing systems. International Journal of Production Economics. 2009;120:301-14.

[128] Hilgers A, Boersma BJ. Optimization of turbulent jet mixing. Fluid Dynamics Research. 2001;29:345-68.

[129] Hao J-K, Galinier P, Habib M. Métaheuristiques pour l'optimisation combinatoire et l'affectation sous contraintes. Revue d'intelligence artificielle. 1999;13:283324.

[130] Belavendram N. Application of Genetic Algorithms for Robust Parameter Optimization. International Journal of Automotive and Mechanical Engineering. 2010;2:211-20.

[131] Kamal M, Rahman MM. Fatigue life estimation based on continuum mechanics theory with application of genetic algorithm. International Journal of Automotive and Mechanical Engineering. 2015;11:2686-98.

[132] Reeves CR. Modern heuristic techniques for combinatorial problems: John Wiley \& Sons, Inc.; 1993.

[133] Aarts EH, Lenstra JK. Local search in combinatorial optimization: Princeton University Press; 1997.

[134] Lebbar G, El Barkany A, Jabri A. Scheduling Problems of Flexible Manufacturing Systems: Review, Classification and Opportunities. International Journal of Engineering Research in Africa. 2016;26:142-60.

[135] Dahane M, Dellagi S, Clementz C, Rezg N. Development of joint maintenance and production strategies in a subcontracting environment. International Journal of Production Research. 2011;49:6937-61.

[136] Liu X, Tu YL, Zhang J, Watson LG. A genetic algorithm heuristic approach to general outsourcing capacitated production planning problems. International Journal of Production Research. 2008;46:5059-74. 